\title{
SIMULERING DEMPER URO OG GIR MINDRE TVANGSBRUK
}

\author{
Psylkisk helsevern. Personalet på en psykiatrisk \\ døgnavdeling opplever simulering som en nyttig øvelse.
}

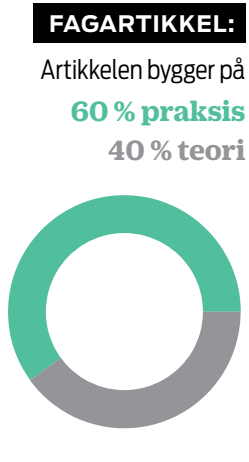

DOI-NUMMER:

10.4220/Sykepleiens.2016.56183

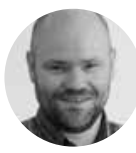

Erling Moldal, spesialrådgiver, psykiatrisk klinikk Lovisenberg Diakonale Sykehus

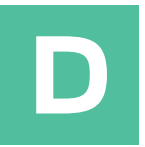

enne artikkelen viser hvordan medisinsk simulering kan brukes til å bedre kommunikasjon og samhandling mellom ansatte ved en psykiatrisk døgnavdeling i uro-/utageringssituasjoner. Vi vil også vise hvordan treningsformen gjør at man reflekterer over handlingsalternativer for å redusere bruk av tvang.

Medisinsk simulering har i flere år vært brukt i somatiske avdelinger for å sette personalet bedre stand til å håndtere kriser og komplekse hendelser. Boet m.fl. (1) viser at treningsformen påvirker klinisk praksis positivt.

Medisinsk simulering har inntil nylig i hovedsak blitt brukt innenfor somatiske helsetjenester. Sykepleien har tidligere publisert artikler om medisinsk simulering ved blant annet intensivavdelinger (2). I 2013 arrangerte SIMsenteret ved Oslo universitetssykehus det første instruktørkurset spesielt beregnet på ansatte innen i psykisk helsevern.

BEDRET PASIENTSIKKERHET. Simuleringstrening gir deltakerne mulighet til å øve på ferdigheter som bidrar til å øke pasientsikkerheten. Opprinnelig ble simuleringstrening brukt i flybransjen. Her hadde man sett at et stort antall uønskete hendelser skyldtes dårlig kommunikasjon og manglende prioritering av oppgaver i krisesituasjoner. Metoden ble senere adoptert av medisinske avdelinger.

Gaba m.fl. (3) har beskrevet 15 nøkkelpunkter for å utnytte ressursene i teamet best mulig for å forebygge og håndtere en krise: Crisis Resource Managment (CRM). Målet med CRM er å utnytte tilgjengelige ressurser best mulig for å få optimal pasientsikkerhet og -behandling. Hensikten er, $\mathrm{i}$ tillegg til å bli bedre til å håndtere akutte kriser, å forebygge kritiske situasjoner (3).

Psykiatrisk klinikk ved Lovisenberg Diakonale Sykehus består av sju lukkete sengeposter. Antall innleggelser årlig er cirka 1000, og en stor andel av pasientene behandles for psykoselidelser, ofte i kombinasjon med rusbruk. Pasientens symptomer varierer, men bærer i noen tilfeller preg av paranoide vrangforestillinger. Dette kan føre til mistenksomhet og aggresjon rettet mot personalet. En del av pasientene mottar dessuten behandling mot sin vilje, noe som innebærer innskrenkning av personlig frihet. Det kreves gode kommunikasjonsferdigheter og evne til samhandling for å kunne ivareta pasienten best mulig ved denne type behandling.
HAR ARBEIDET SYSTEMATISK. Psykiatrisk klinikk ved Lovisenberg Diakonale Sykehus har arbeidet systematisk på flere områder for å forebygge og håndtere aggressiv atferd ved avdelingen. Det arrangeres regelmessige samhandlingskurs og trening for å bedre kommunikasjon og samarbeid blant personalet. Man bruker standardiserte skjemaer for å kartlegge voldsrisiko (V-Risk-10/ HCR-20) og iverksette aggresjonsforebyggende tiltak.

I tillegg har man startet et prosjekt for rutinemessig å snakke med pasientene om mulig voldsrisiko (4). Da Helse Sør-Øst startet opp med utdanning av instruktører i medisinsk simulering våren 2013, så klinikken dette som et nyttig supplement til det eksisterende kurstilbudet. Avdelingen har nå utdannet seks instruktører som rullerer på å ha ansvar for klinisk simulering i klinikken.

HVA ER MEDISINSK SIMULERING? Den medisinske simuleringen ledes av en utdannet instruktør. Instruktøren har forberedt et scenario som skal ligge så nært en reell situasjon i klinikken som mulig. Det kan for eksempel være behandling av en pasient med paranoide vrangforestillinger og problemer med aggresjon.

I en del tilfeller kan det være
Fakta

Hoved-

budlskap:

Psykiatrisk klinikk ved Lovisenberg Diakonale Sykehus har de siste to årene tatt i bruk medisinsk simulering for å øve ferdigheter ved håndtering av uro- og utageringssituasjoner. Vi har erfart at metoden er et nyttig supplement til tradisjonell samhandlingstrening.

\section{Nøkkelord}

Les mer og finn litteraturhenvisninger på våre nettsider - Simulering - Psykisk helsevern - Kommunikasjon - Samhandling 


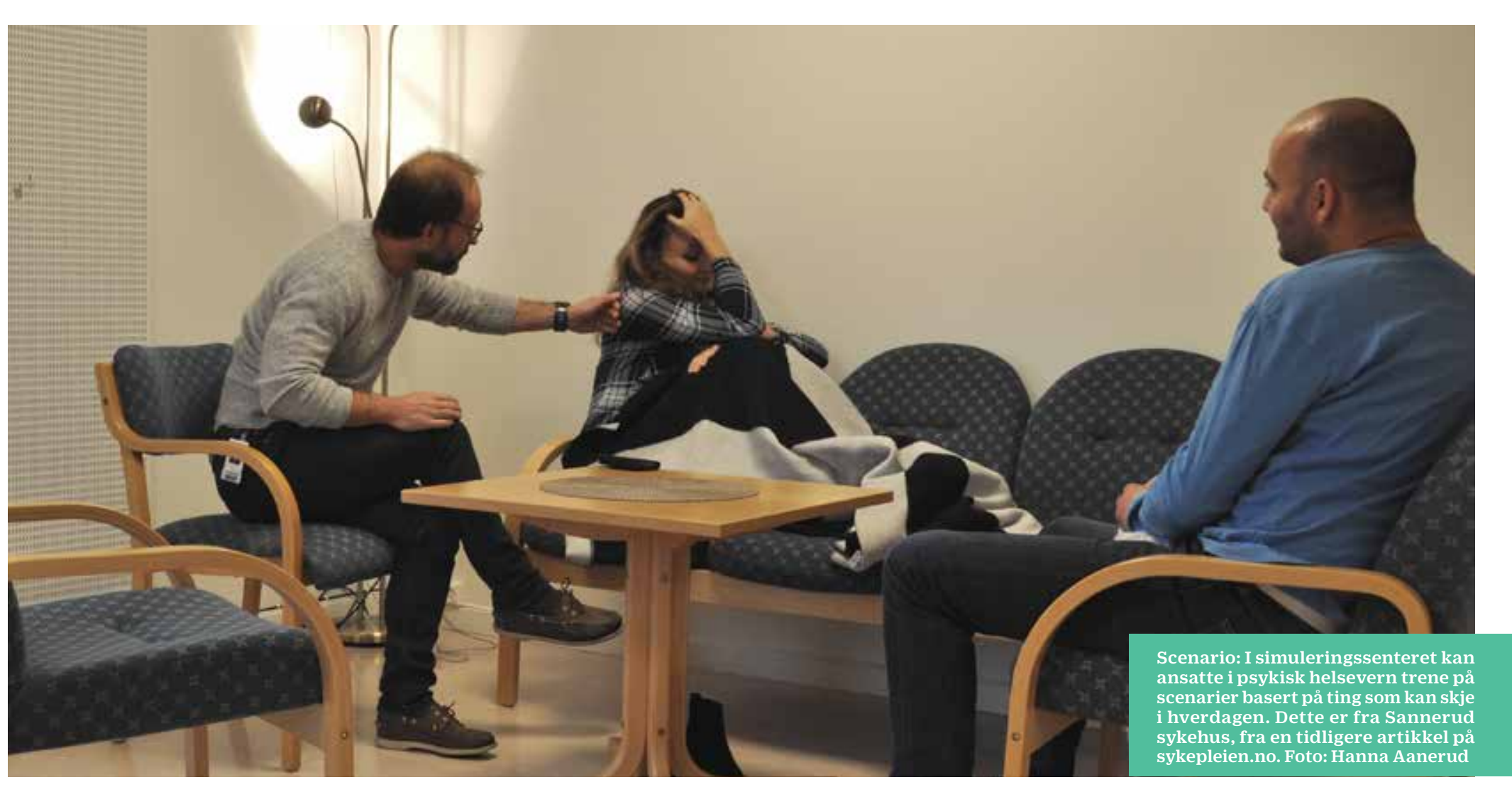

aktuelt at deltakerne får tilsendt relevant fagstoff for å forberede seg, såkalt pre-briefing. Simuleringstreningen foregår i et lokale som er tilrettelagt for å likne mest mulig på en sykehuspost. Ved psykiatrisk klinikk bruker man et stort møterom som kurslokale. Rommet deles av med mobile skillevegger og møbleres med senger, stoler og så videre. Man har dessuten en eller to markører som spiller rollen som pasient. Markøren(e) har på forhånd fått instruksjoner om hvordan de skal agere i situasjonen og hvordan de skal reagere på ulike intervensjoner fra personalet.

Antall deltakere varierer fra fire til åtte. Instruktøren påpeker at deltakerne ikke deltar i et rollespill, men at de i størst mulig grad skal være seg selv som fagperson på egen arbeidsplass.
Deltakerne på simuleringene kommer som oftest fra flere sengeposter, og dette gjenspeiler virkeligheten når personale fra flere poster skal hjelpe hverandre i tilspissete situasjoner.

Selve treningen består av tre faser:

1) Briefing: Personalet som er til stede på treningen får en innføring i dagens tema samt prinsippene for medisinsk simulering. Deltakerne orienteres om dagens læringsmål og rammene for treningen, for eksempel tilgjengelig tid.

2) Gjennomføring: Scenarioet gjennomføres ved at markøren(e) spiller rollen de har fått gjennomført og personalet håndterer situasjonen i fellesskap på best mulig måte. Instruktøren er i denne fasen observatør og spesielt oppmerksom på ferdigheter som

\section{«Vi har ikke nok erfaring med medisinsk simulering til å vite hvordan det har påvirket klinisk praksis.»}

kommunikasjon mellom personal og pasient, kommunikasjon mellom personalet, prioritering av oppgaver, oppgavedeling og ledelse. I noen tilfeller vil gjennomføringen filmes slik at man i fase tre kan se nærmere på enkelte sekvenser i forløpet.

3) Debrifing: I denne fasen skal deltakerne først beskrive så objektivt så mulig hva som skjedde i scenarioet, uten å vurdere hva som var bra eller mindre bra. Hensikten er å skaffe en felles forståelse av hendelsesforløpet. Neste trinn er å analysere gjennomføringen av scenarioet: Hva var den enkeltes rolle og oppgaver? Hva gikk bra? Hva ville man gjort annerledes i en tilsvarende situasjon? Hva var det kritiske punktet (vendepunktet) i scenarioet? Hvilke valg tok man, og hva var handlingsalternativene? Siste trinn er å diskutere overføringsverdien til arbeidet i klinikken. Hva har man erfart i dagens simulering som kan anvendes i en reell situasjon? Debrifingen ansees å være den viktigste i simuleringstreningen. Ved refleksjon i teamet kan man rette oppmerksomheten 
$\rightarrow$ mot hvordan personalet kan forbedre praksis for bedre å ivareta den enkelte pasient.

BRUK OG ERFARING. Psykiatrisk klinikk er lokalisert på tre steder sentralt i Oslo. Denne erfaringsoppsummeringen baserer seg på simuleringstreninger ved et av stedene som består av tre psykiatriske intensivposter.

I tillegg til regelmessige dagskurs i sikkerhet og samhandling, avvikler avdelingen ukentlig treninger for å vedlikeholde personalets kompetanse i å håndtere uro og utagering. Foruten handlingskompetanse i «skarpe» situasjoner, legges det stor vekt på å forebygge uro. Sentrale temaer er kommunikasjon og tidlig intervensjon for å dempe situasjoner.

Man veksler mellom å la den ukentlige treningen bestå av ordinær samhandlingstrening og medisinsk simulering. Erfaringene man deler her, er tilbakemeldinger fra 22 deltakere som deltok på fire simuleringstreninger vinteren 2014/15. Det er benyttet et spørreskjema som fylles ut anonymt.

Deltakerne som fylte ut skjemaet, jobber nesten utelukkende i sykepleietjenesten, og det er god spredning mellom «nyansatte» og mer erfarne medarbeidere. Nesten halvparten av deltakerne hadde deltatt i simuleringstreninger tidligere, i gjennomsnitt på 2,67 ganger. 18 av 22 respondenter svarte at de i stor eller svært stor grad kjenner til hensikten med medisinsk simulering. Samtlige svarte at de i stor eller svært stor grad mener medisinsk simulering er nyttig for eget arbeid.

Tretten av respondentene svarte at det bare i noen grad var satt av nok tid til simuleringstreningene, og da respondentene ble bedt om å foreslå forbedringer av simuleringstreningene hadde tre deltakere foreslått "mer tid" og «mer tid til debrifing». Halvparten av deltakerne mente at lokalene i stor eller svært stor grad er egnet til denne type trening, mens resten mente lokalene i liten eller noen grad var egnet.

OPPLEVES SOM NYTTIG. Vi har ikke nok erfaring med medisinsk simulering til å vite hvordan det har påvirket klinisk praksis. Imidlertid tyder både de skriftlige og muntlige tilbakemeldingene fra deltakerne på at deltakerne opplever treningene som nyttige for

\section{«Deltakerne opplever treningene som nyttige for eget arbeid.»}

eget arbeid. En utfordring ser ut til å være å tilpasse scenarioene slik at det blir mer tid til refleksjon, eventuelt øke tiden som brukes til trening. Psykiatrisk klinikk har så langt brukt simulering for å trene på å håndtere uro og utagering, men klinikken ser for seg å utvide bruksområdet for å øke de kliniske ferdighetene også på andre områder.

\section{REFERANSER:}

Boet S, Bould MD, Fung L, Oosa H, Perrier L, Tavares W, Reeves S, Tricco AC. Transfer of learning and patient outcome in simulated crisis resource mangament: a systemativ review. Canadian Journal of anaestesia 2014; 6: 571-582.

2. Karlsen T, Ballangrud R, Haugom VT, Mæhlum EH, Mæhlum K. Trener på virkeligheten. Sykepleien 2009; 15: 31-34.

3. Rall M. Dieckmann P. Crisis resource management to improve patient safety. Vienna: Euroanestesia, 2005. Veland M, Jacob A. Jobber for mindre tvang. Sykepleien 2014; 09: 50-51.

\section{FAGARTIKLER:}

Fagartikler kan sendes til torhild.apall@sykepleien.no

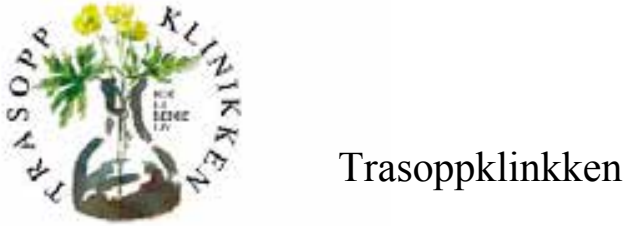

Trasoppklinikken er en stiftelse som inngår i tverrfaglig spesialisert rusbehandling innenfor Helse Sør-Øst RHF. Målgruppen er alkohol- og medikamentavhengige/ blandingsmisbrukere og deres familier/pårørende.

Klinikken består av poliklinikk med vurderingskompetanse, dagbehandling for ruspasienter og familiemedlemmer, døgnklinikk med 35 plasser hvorav 6 plasser til elektiv avgiftning

\section{TRASOPPKLINIKEN SØKER AVDELINGSLEDER TIL POLIKLINIKKEN - NY UTLYSNING}

Har du lyst til å jobbe som leder, men ikke miste kontakten med pasientene? Da kan det hende at Trasoppklinikken har lederjobben for deg.

Som avdelingsleder for poliklinikken vil du ha personalansvar for en tverrfaglig sammensatt personalgruppe på 10 behandlere. Behandlergruppen består av leger, psykologer, sykepleiere og sosionomer, de fleste med spesialisering eller videreutdanning relevant for rusfeltet. Du vil ha delansvar for måloppnåelse og rapportering jf. produksjonsavtale med Helse Sør-Øst, og samarbeide med faglig nestleder om det faglige ansvaret for poliklinisk drift. I tillegg vil du beholde kontakten med pasientgruppen ved at du har en mindre andel pasientkontakt individuelt, og som leder av terapeutiske grupper. Som avdelingsleder inngår du i klinikkens ledergruppe, og fag- og kvalitetsteam.

Du må ha minimum 3-årig helse- og sosialfaglig utdannelse eventuelt psykolog/lege. Erfaring fra Tverrfaglig spesialisert behandling er en fordel(TSB). Erfaring og/eller videreutdanning innen ledelse vektlegges.

Du må trives med å jobbe både selvstendig og i team. Personlig egnethet er en forutsetning. Du må kunne snakke og skrive godt norsk.

\section{Tiltredelse: snarest}

Vi har også ledig svangerskapsvikariat på Dagbehandling-rus $100 \%$ stilling med oppstart 1. mai 2016.

For nærmere informasjon se www.trasoppklinikken.no

Vi kan tilby

- En engasjerende arbeidsplass

- Ledelse av tverrfaglig personalgruppe

- Mulighet for videre-/etterutdanning og faglig oppdatering

- Pensjonsordning i KLP

- Lønn etter avtale

Nærmere opplysninger kan fås ved henvendelse til faglig nestleder Henning Meling eller klinikksjef Kari Nådland på tlf. 23348200

Søknad sendes: Trasoppklinikken, Trasoppterassen 25, 0672 Oslo.

Søknadsfrist for begge stillingene: 22 . februar 2016 